\title{
Manajemen Asuhan Kebidanan Intranatal Pada Ny " $N$ " dengan Usia Kehamilan Preterm di RSUD Syekh Yusuf Gowa Tanggal 01 Juli 2018
}

\author{
${ }^{1}$ Indah, ${ }^{2}$ Firdayanti, ${ }^{3}$ Nadyah
}

\begin{abstract}
ABSTRAK
Pendahuluan persalinan normal adalah proses pengeluaran hasil konsepsi dari dalam uterus pada umur kehamilan 37-42 minggu dengan ditandai adanya kontraksi uterus yang menyebabkan terjadinya penipisan dan dilatasi serviks. Terjadinya persalinan normal bukan berarti tidak ada komplikasi, tetapi melainkan banyak kemungkinan hal yang bisa terjadi. Salah satu komplikasinya adalah persalinan preterm.
\end{abstract}

Metode jenis penelitian ini adalah studi kasus dengan pendekatan Manajemen Asuhan Kebidanan Intranatal pada Ny "N" dengan Usia Kehamilan Preterm di RSUD Syekh Yusuf Gowa Tahun 2018 sesuai dengan 7 langkah Varney dan pendokumentasian dalam bentuk SOAP.

Hasil penatalaksanaan Asuhan Persalinan Preterm pada Ny "N" yaitu dilakukan dengan pemberian asuhan yang sesuai standar operasional prosedur serta melakukan upaya pencegahan komplikasi terutama terjadinya gawat janin, partus lama, perdarahan postpartum, hipotermi, asfiksia dan Berat Badan Lahir Rendah (BBLR) serta dilakukannya pemantauan dan asuhan dari kala I sampai kala IV.

Kesimpulan dari kasus yaitu asuhan 7 langkah Varney dan pendokumentasian dalam bentuk SOAP yang digunakan untuk proses penyelesaian masalah kebidanan telah dilaksanakan pengkajian berupa pemantauan dan analisa data pada Ny "N" dengan Usia Kehamilan Preterm di RSUD Syekh Yusuf Gowa Tahun 2018 yakni dari kala I sampai kala IV, tidak ditemukannya komplikasi pada ibu ditandai dengan tanda-tanda vital dalam batas normal, serta bayi mengalami asfiksia ringan disertai BBLR.
*UIN Alauddin Makassar

Kata kunci :

Persalinan Preterm

7 Langkah Varney

\section{PENDAHULUAN}

Persalinan normal adalah proses pengeluaran hasil konsepsi yang dapat hidup dari dalam uterus melalui vagina ke dunia luar yang terjadi pada kehamilan yang cukup bulan (37-42 minggu) dengan ditandai adanya kontraksi uterus yang menyebabkan terjadinya penipisan, dilatasi serviks, dan mendorong janin keluar melalui jalan lahir dengan presentase belakang kepala tanpa alat atau bantuan (lahir spontan) serta tidak ada komplikasi pada ibu dan janin (Eka Puspita, 2014). 
Terjadinya persalinan normal bukan berarti tidak ada permasalahan dalam persalinan, tetapi melainkan banyak kemungkinan hal yang bisa terjadi dimana dinamakan dengan komplikasi pada saat persalinan. Komplikasi persalinan adalah kondisi dimana ibu dan janinnya terancam yang disebabkan oleh gangguan langsung saat persalinan serta menjadi salah satu penyebab terjadinya kematian ibu bersalin maupun janinnya. Adapun beberapa komplikasi yang terjadi pada saat persalinan di antaranya Ketuban pecah dini (KPD), persalinan preterm, kehamilan postmatur, malposisi dan malpresentasi, pre-eklampsia dan eklampsia, kehamilan kembar (gemelli), dan distosia bahu. Hal ini dapat menyebabkan tingginya Angka Kematian Ibu (AKI) dan Angka Kematian Bayi (AKB) pada saat persalinan.

Menurut laporan World Health Organization (WHO) tahun 2014 bahwa Angka Kematian Ibu (AKI) di dunia mencapai 289.000 jiwa. Dimana terbagi atas beberapa Negara, antara lain Amerika Serikat 9.300 jiwa, Afrika Utara 179.000 jiwa dan Asia Tenggara 16.000 jiwa. Angka kematian ibu di Negara- Negara Asia Tenggara yaitu Indonesia 190 jiwa, Vietnam 49 jiwa, Thailand 26 jiwa, Brunei 27 jiwa, Malaysia 29 jiwa. Sebagian besar kematian ibu terjadi di negara berkembang karena kurang mendapat akses pelayanan kesehatan, kekurangan fasilitas, terlambatnya pertolongan persalinan disertai keadaaan social ekonomi dan pendidikan masyarakat yang masih tergolong rendah (WHO, 2014).

Angka Kematian Ibu (AKI) dan Angka Kematian Bayi (AKB) merupakan salah satu indikator untuk mencerminkan derajat kesehatan ibu dan anak, serta cerminan dari status kesehatan suatu negara. Hasil survey demografi dan kesehatan Indonesia (SDKI) tahun 2015, AKI yaitu 305 per 100.000 kelahiran hidup yang mengalami penurunan dari tahun 2012 yaitu 359 per 100.000 kelahiran hidup. Sedangkan AKB sendiri menurut survey penduduk antar sensus (SUPAS) pada tahun 2015 yaitu 22,23 per 100.000 kelahiran hidup, yang artinya sudah mencapai target MDG 2015 sebesar 23 per 1.000 kelahiran hidup (KemenKes, 2016). Indonesia masih tergolong tinggi pada Negara-negara di ASEAN (Association South East Asian Nation) dan menjadi salah satu Negara yang menjalankan program Milleneum Development Goals (MDG's), memiliki target menurunkan Angka Kematian Ibu (AKI) menjadi 102 per 100.000 kelahiran hidup dan Angka Kematian Bayi (AKB) menjadi 20 per 1000 kelahiran hidup pada tahun 2015. Berdasarkan data yang di peroleh dari Dinas Kesehatan Provinsi Sulawesi Selatan pada tahun 2016, AKI mencapai 153 orang per 
100.000 kelahiran hidup. Sedangkan AKB terbanyak (48\%) terjadi pada bulan pertama atau masa neonatus, dan penyebab terbanyak (44\%) kematian neonatus adalah prematuritas. Demikian juga dengan Dinas Kesehatan Kabupaten Gowa, AKI yang didapatkan sebanyak 14 orang atau 111 per 100.000 kelahiran hidup dan AKB yang dilaporkan sebanyak 87 kematian Neonatal (7 per 1000 kelahiran), 16 kematian Bayi (1 per 1000 kelahiran) terjadi pada tahun 2015 (DinKese, 2016).

Penyebab terjadinya kematian bayi dan balita serta berbagai komplikasi yang tinggi pada masa neonatus, sebagian besar disebabkan karena gangguan pernapasan dan prematuritas. Prematuritas atau persalinan preterm adalah persalinan yang terjadi pada kehamilan 20 sampai 36 minggu. Mekanisme terjadinya persalinan preterm dimulai dengan adanya kontraksi uterus dan dilatasi serviks serta ketuban pecah, kejadian ini sebagai keadaan patologis (Nur Mukmin, 2016).

Angka kejadian persalinan preterm pada umumnya adalah sekitar 6-10\%. Hanya 1,5\% persalinan terjadi pada umur kehamilan kurang dari 32 minggu dan $0,5 \%$ pada kehamilan kurang dari 28 minggu. Secara biologis, mekanisme persalinan preterm disebabkan oleh hipoksia, stress oksidatif, dan infeksi maternal. Badan Kesehatan Dunia (Word Health Organization) menyatakan bahwa bayi premature dalah bayi yang lahir pada usia kehamilan 37 minggu atau kurang. Adapun faktor penyebab langsung kematian ibu adalah perdarahan 40-60\%, preeklampsia $20-30 \%$, infeksi $20-30 \%$ serta kejadian ketuban pecah dini (KPD) yang tidak segera mendapatkan penanganan sehingga KPD menjadi masalah yang serius yang dapat meningkatkan morbiditas dan mortalitas perinatal serta menyebabkan infeksi pada ibu (Zainal Alim,Yeni Agus Safitri, 2016).

Permasalahan yang terjadi pada persalinan preterm bukan saja pada kematian perinatal, melainkan bayi prematur ini sering pula disertai dengan kelainan seperti RDS (Respiratory Distress Syndrome), perdarahan dan kelainan neorologik karena persalinan dan kelahiran prematur masih merupakan komplikasi berbahaya dengan akibat yang signifikan pada ibu dan bayi baru lahir (Prawirohardjo, 2014).

Kesulitan utama dalam persalinan preterm adalah perawatan bayi preterm, yang semakin muda usia kehamilannya semakin besar morbiditas dan mortalitas. Menurut Saifuddin (2007) faktor yang menimbulkan terjadinya persalinan preterm seperti faktor 
maternal yang meliputi riwayat premature sebelumnya, umur ibu, paritas, plasenta previa, kelainan serviks (serviks inkompetensi), hidramnion, infeksi intraamnion, hipertensi dan trauma. Faktor janin diantaranya kehamilan kembar (gemelli), kematian janin dalam rahim/Intra Uterin Fetal Death (IUFD), dan cacat bawaan (kelainan kongenital), serta faktor perilaku meliputi ibu yang merokok dan minum alkohol (Tri Anasari, 2016).

Berdasarkan data yang diperoleh dari Rekam Medik Rumah Sakit Umum Daerah Syekh Yusuf Kabupaten Gowa menunjukkan jumlah persalinan pada periode 2015 yaitu 1.804 persalinan yang diantaranya terdapat $65(3,60 \%)$ kasus persalinan preterm. Pada tahun 2016 yaitu 1.578 persalinan yang diantaranya 90 (5,70\%) kasus persalinan preterm, sedangkan pada tahun 2017 terdapat 2.642 persalinan yang diantaranya terdapat $87(0,52 \%)$ kasus persalinan preterm (Rekam Medik RSUD Syekh Yusuf, 2017). Upaya dalam menurunkan angka kematian bayi dan meningkatkan kesehatan ibu, perlu dilakukan upaya pencegahan

\section{METODE PENELITIAN}

Jenis penelitian ini adalah studi kasus dengan pendekatan Managemen Asuhan Kebidanan sesuai dengan 7 langkah Varney dan pendokumentasian dalam bentuk SOAP. Penatalaksanaan Asuhan dilakukan dengan pemberian asuhan yang sesuai standar operasional prosedur pada kasus yang diteliti yaitu

\section{HASIL PENELITIAN}

Penelitian ini dilakukan di RSUD Syekh Yusuf Gowa tepat dengan terjadinya kejadian persalinan preterm di masa yang akan datang, salah satu diantaranya adalah dengan melakukan pengawasan ketat dan membutuhkan program yang terarah dalam memberikan edukasi dan penanganan medik yang tepat terhadap faktor-faktor resiko yang memicu terjadinya proses persalinan preterm, agar mendapat asuhan persalinan yang aman dan memuaskan. Sehingga perlu dilakukan asuhan pada ibu hamil untuk mendeteksi dini terjadinya persalinan pretrem karena diagnosis yang cepat dan penanganan yang adekuat dapat menyelamatkan janin.

Maka dari itu, berdasarkan dari latar belakang di atas, maka penulis tertarik melakukan tinjauan kasus untuk membahas masalah persalinan preterm dengan judul "Manajemen 
Asuhan Kebidanan Intranatal pada Ny "N" dengan Usia kehamilan Preterm di RSUD SyekhYusuf Gowa Tahun 2018”. persalinan preterm serta melakukan upaya pencegahan komplikasi terutama terjadinya gawat janin, partus lama, perdarahan postpartum, hipotermi, asfiksia dan Berat Badan Lahir Rendah (BBLR) serta dilakukannya pemantauan dan asuhan dari kala I sampai kala IV. pembahasan tentang asuhan kebidanan intranatal pada Ny"N" dengan Usia kehamilan preterm pada tanggal 1 Juli 2018. Pembahasan ini dibuat berdasarkan landasan teoritis dan studi kasus yang dapat dianalisa secara teoritis untuk memudahkan memahami kesenjangan dan kesesuaian yang terjadi pada kasus ini dengan berdasarkan pada pendekatan asuhan kebidanan dengan tujuh langkah varney yakni : pengumpulan data dasar, merumuskan diagnosis atau masalah potensial, melaksanakan tindakan segera atau kolaborasi, merencanakan tindakan asuhan kebidanan

\section{Kala I}

Berdasarkan hasil pengkajian pada kasus Ny "N" didapatkan data subjektif dan objektif menunjukkan bahwa diagnosis inpartu kala I fase laten dengan Usia Kehamilan Preterm. Hasil yang diperoleh pada kasus Ny "N" yaitu pada kala I berlangsung \pm 6 jam, keadaan ibu dan janin baik, dan tidak ada komplikasi yang terjadi pada ibu dan bayi. Dengan demikian seorang bidan harus tetap memberikan dukungan psikologis dan spiritual kepada ibu dan keluarga sangat penting agar tetap tenang dalam menghadapi persalinannya yaitu dengan memperbanyak berdoa, berdzikir, istighfar, membaca dan mendengarkan lantunan ayat suci Al-Quran

\section{Kala II}

Berdasarkan pengkajian pada kala II pada kasus Ny "N" didapatkan data subjektif ibu merasakan adanya dorongan kuat untuk meneran. Sedangkan data objektif didapatkan tampak perineum menonjol, vulva dan vagina membuka, pada pemeriksaan dalam didapatkan pembukaan serviks telah lengkap. Pada kasus Ny "N" kala II berlangsung normal yaitu bayi lahir spontan pada tanggal 1 Juli 2018 jam 22.25 WITA, segera menangis, dan bergerak aktif dengan berat badan lahir 2300 gram, panjang badan $46 \mathrm{~cm}$. Tinggi fundus uteri setinggi pusat. Berdasarkan pengkajian yang telah dilakukan pada Ny "N" di kala II tidak ditemukan kesenjangan antara teori dan kasus. 


\section{Kala III}

Pada kasus Ny"N" didapatkan hasil pemeriksaan dalam keadaan normal ditandai dengan uterus teraba keras dan bundar, tinggi fundus uteri setinggi pusat yang berarti kala III berlangsung normal, serta tidak ada kesenjangan antara teori dan praktek yang dilakukan.

\section{Kala IV}

Pada kasus Ny"N" didapatkan kontraksi uterus baik teraba keras dan bundar, tinggi fundus uteri 1 jari bawah pusat, kandung kemih kosong, jumlah perdarahan $\pm 150 \mathrm{cc}$. Hasil evaluasi ini membuktikan bahwa kala IV berlangsung normal dan tidak ada penyulit serta tidak ada kesenjangan antara teori dan praktek.

\section{PEMBAHASAN}

\section{Kala I}

Berdasarkan hasil pengkajian pada kasus Ny "N" didapatkan data subjektif dan objektif menunjukkan bahwa diagnosis inpartu kala I fase laten dengan Usia Kehamilan Preterm. Hasil yang diperoleh pada kasus Ny "N" yaitu pada kala I berlangsung \pm 6 jam, keadaan ibu dan janin baik, dan tidak ada komplikasi yang terjadi pada ibu dan bayi. Dengan demikian seorang bidan harus tetap memberikan dukungan psikologis dan spiritual kepada ibu dan keluarga sangat penting agar tetap tenang dalam menghadapi persalinannya yaitu dengan memperbanyak berdoa, berdzikir, istighfar, membaca dan mendengarkan lantunan ayat suci Al-Quran masalah yang bisa muncul serta menjadi ancaman terjadinya persalinan preterm seperti pecahnya selaput ketuban, presentase janin rendah, adanya nyeri punggung bawah, perdarahan bercak, perasaan menekan daerah serviks serta terjadinya kontraksi yang berulang (2-3 kali dalam 10 menit). Demikian pada hasil pengamatan didapatkan keluarnya cairan ketuban merembes melalui vagina. Begitu juga pada saat pemeriksaan dalam, didapatkan cairan dan selaput ketuban sudah tidak ada lagi.

Persalinan preterm adalah persalinan yang terjadi sebelum usia kehamilan 37 minggu (antara 20-37 minggu) atau dengan berat janin kurang dari 2500 gram (Dhina Novi Ariana,2012). Diagnosis persalinan preterm dapat ditegakkan berdasarkan usia kehamilan. Usia kehamilan dapat diketahui berdasarkan hari pertama haid terakhir pergerakan janin 
pertama kali serta pengukuran tinggi fundus uteri. TFU normal pada umur kehamilan 37-40 minggu pada persalinan preterm adalah 2 jari dibawah prosessus xypoideus. Pada kasus $\mathrm{Ny}$ "N" didapatkan TFU 3 jari atas pusat. Hal ini menunjukkan bahwa usia kehamilan belum aterm jika dilihat berdasarkan pengukuran tinggi fundus uteri.

Dilihat dari keadaan ibu dengan kondisi usia kehamilan tidak cukup bulan atau preterm maka peran seorang bidan yaitu tetap memberikan dukungan psikologis dan spiritual kepada ibu dan keluarga dengan senantiasa berdoa dan berdzikir kepada Allah swt. serta memberikan pemahaman yang logis dari mitos-mitos yang beredar dari kalangan masyarakat awam agar segala kesulitan yang dialami dimudahkan karena atas izin- Nya, serta diberikan kesabaran dan ketabahan hati serta kemudahan dalam proses persalinan. Dengan diberikan dukungan kepada ibu dan keluarga semata-mata untuk menjadikan hati ibu tenang dan siap fisik dan mental dalam menghadapi persalinan. Masalah-masalah yang bisa terjadi dari persalinan preterm ini maka ibu dan keluarga berhak untuk mengetahuinya, oleh karena itu bidan berperan untuk tetap memberikan dukungan psikologis dan spiritual kepada ibu dan keluarga agar tetap berdoa dan berdzikir kepada Allah SWT. agar masalah- masalah tersebut tidak terjadi dan memberikan pemahaman bahwa Allah swt. tidak memberikan cobaan kepada umatnya diluar batas kemampuan umatnya sendiri. Dengan dukungan ini ibu yakin dengan ikhtiar serta tawakal pasti bisa dan mampu melewati persalinannya dengan lancar.

\section{Kala II}

Berdasarkan pengkajian pada kala II pada kasus Ny "N" didapatkan data subjektif ibu merasakan adanya dorongan kuat untuk meneran. Sedangkan data objektif didapatkan tampak perineum menonjol, vulva dan vagina membuka, pada pemeriksaan dalam didapatkan pembukaan serviks telah lengkap.

Masalah potensial yang dapat terjadi pada persalinan preterm yaitu asfiksia merupakan keadaan pada bayi baru lahir yang mengalami gagal bernapas secara spontan dan teratur segera setelah lahir. Hipotermi yaitu suhu bayi <36,5 0C serta kaki dan tangan teraba dingin. Bayi berat lahir rendah yaitu berat badan pada bayi baru lahir $<2500$ gram (Prawirohardjo, 2014).

Asfiksia adalah merupakan keadaan dimana bayi tidak dapat segera bernapas secara spontan dan teratur segera setelah lahir. Hal ini erat kaitannya dengan hipoksi pada janin 
dalam uterus. Hipoksia ini berhubungan dengan faktor-faktor yang timbul dalam kehamilan, persalinan atau segera lahir (Nugroho, 2015).

Hasil penelitian sebelumnya oleh Vina Oktavionita ditemukan bahwa bayi yang BBLR mengalami keadaan tidak asfiksia sebanyak 83'bayi (35,8\%), sedangkan yang asfiksia sebanyak 27 (11,6\%). Berdasarkan ukuran Rasio Prevalensi (RP) menunjukkan bahwa kejadian asfiksia untuk bayi kurang bulan adalah sebesar 11,6\% dan bayi cukup bulan 9,9\%. Penelitian ini menyatakan bahwa tidak ada perbedaan yang signifikan dengan kejadian asfiksia antara bayi kurang bulan dan bayi cukup bulan dilihat berdasarkan hasil analisis statistik diperoleh nilai $p$-value $>0,05$. Hipotermi terjadi karena sistem pengaturan suhu tubuh belum matang pada bayi yang baru lahir preterm disebabkan karena organ yang belum matur dan belum bisa menjalankan fungsinya dengan baik. Hal ini sesuai dengan penelitian sebelumnya yang mengatakan bahwa bayi yang lahir preterm mengalami suhu tubuh yang tidak stabil karena tidak dapat menghasilkan panas yang cukup sebab kekurangan lemak tubuh. Berdasarkan hasil penelitian sebelumnya ditemukan bayi lahir pretem terjadi peningkatan resiko ketidakstabilan suhu tubuh dikarenakan kekurangan lemak tubuh (Sari Pediatri, 2012).

Bayi berat lahir rendah adalah bayi lahir dengan berat badan kurang dari 2500 gram tanpa memandang usia kehamilan. Bayi dengan berat badan lahir kurang dari 2500 gram atau sama dengan 2500 gram disebut prematur dengan masa gestasi $<37$ minggu (Vivian Nanny Lia Dewi, 2011). Berdasarkan hasil penelitian Vina Oktavionita dengan menggunakan 232 responden bayi dengan BBLR pada tahun 2015 dan 2016 yang dipilih dengan tekhnik Quota Sampling yaitu pengambilan sampel dan ini menunjukkan bahwa bayi berat lahir rendah dimana bayi kurang bulan yang BBLR sebanyak 110 (47,4\%) dibandingkan bayi cukup bulan yang BBLR sebanyak 122 bayi $(52,6 \%)$

Pada kasus Ny"N" didapatkan bayi lahir spontan dengan presentasi belakang kepala tanggal 1 Juli 2018 jam 22.25 WITA dengan jenis kelamin perempuan dengan BB :

2300 gram, PB : $46 \mathrm{~cm}$. Setelah bayi lahir cek fundus uteri untuk memastikan kehamilan tunggal, kemudian memberitahu ibu untuk penyuntikan oksitosin, suntik oksitosin. Setelah ibu melewati proses persalinan, ibu diingatkan untuk bersyukur atas nikmat keselamatan yang diberikan dan senantiasa menerima dengan lapang dada apapun yang terjadi karena segala sesuatu itu semuanya terjadi atas rencana Allah swt kepada umat-Nya. Pada kasus Ny "N" 
didapatkan bayi dengan apgar score 7/10, suhu 36,5 0C, berat badan lahir 2300 gram. Bayi berat lahir rendah adalah bayi yang lahir dengan berat badan $<2500$ gram tanpa memandang masa kehamilan. Bayi dengan berat abdan lahir $<2500$ gram atau sama dengan 2500 gram disebut prematur.

Pada langkah IV ini tidak dilakukan tindakan segera atau kolaborasi. Tindakan ini diambil berdasarkan indikasi yang ditemukan pada langkah sebelumnya. Pada kasus Ny "N" berlangsung normal tanpa ada penyulit, bayi lahir spontan tanggal 1 Juli 2018 jam 22.25 WITA, menangis kuat, bernapas tanpa bantuan dan bergerak aktif. Pada langkah selanjutnya, berdasarkan intervensi yang dilakukan meliputi melihat ada tanda dan gejala kala II, siapkan alat dan bahan persalinan, pastikan pembukaan lengkap, periksa keadaaan janin, siapkan ibu dan keluarga untuk membantu proses persalinan, dan menganjurkan untuk membaca basmalah saat mulai mengedan, letakkan handuk bersih di atas perut ibu dan underpad di bawah bokong ibu, pimpin persalinan jika kepala sudah membuka vulva 5-6 cm, periksa lilitan tali pusat, tunggu kepala bayi melakukan putaran paksi luar secara spontan, kemudian melanjutkan melahirkan bahu depan dan bahu belakang, setelah kedua bahu bayi lahir dilanjutkan dengan sanggah susur untuk melahirkan badan bayi, setelah bayi lahir jepit dan potong tali pusat kemudian bersihkan badan bayi lalu lakukan penilaian sepintas, dan segerakan untuk IMD.

Inisiasi Menyusu Dini ini untuk menjalin kasih sayang antara ibu dan bayi, selain itu agar bayi tetap mempertahankan suhu tubuh dan menciptakan ikatan batin sambil bayi berada dipelukan ibunya, ibu dianjurkan untuk membisikan kalimat- kalimat tauhid kepada bayinya agar kelak menjadi anak yang solehah

\section{Kala III}

Pada kasus Ny"N" didapatkan hasil pemeriksaan dalam keadaan normal ditandai dengan uterus teraba keras dan bundar, tinggi fundus uteri setinggi pusat yang berarti kala III berlangsung normal, serta tidak ada kesenjangan antara teori dan praktek yang dilakukan.

Berdasarkan teori yang didapatkan asuhan persalinan kala III dimulai segera setelah bayi sampai lahirnya plsenta yang berlangsung tidak lebih dari 30 menit. Setelah bayi lahir uterus teraba keras dengan fundus uteri agak di atas pusat untuk melepaskan plasenta dari dindingnya. Tanda-tanda terlepasnya plasenta yaitu perubahan bentuk dan tinggi fundus uteri, 
tali pusat memanjang, tali pusat terlihat menjulur keluar melalui vulva, semburan darah tibatiba (Walyani, 2015).

Pada kasus Ny "N" dilakukan intervensi yang sesuai yaitu pemberian oksitosin, peregangan tali pusat dan masase uterus. Periksa tinggi fundus uteri untuk memastikan tidak ada janin, pemberian oksitosin dilakukan setelah 1 menit bayi lahir. Setelah itu, suntikkan oksitosin secara IM di sepertiga bagian atas paha ibu dan segera lakukan IMD. Pada kasus Ny"N" melakukan pemberian oksitosin secara IM, kemudian melakukan peregangan tali pusat terkendali untuk melahirkan plasenta, lakukan masase uterus setelah plasenta lahir. Proses pelepasan dan pengeluaran plasenta berlangsung normal tanpa penyulit. Plasenta lahir 5 menit setelah bayi lahir yaitu jam 22.30 WITA, plasenta lahir lengkap dengan kotiledon dan selaput ketuban utuh, perdarahan \pm 200 cc dan segera dilakukan IMD untuk mencegah terjadinya hipotermi.

Berdasarkan hasil penelitian Heny Ekawati menggunakan tekhnik sampling dengan sampel 21 bayi dengan menyatakan bahwa pelaksanan IMD yang diberikan pada bayi baru lahir selama \pm 1 jam setelah bayi lahir memberikan pengaruh terhadap perubahan suhu tubuh bayi terutama pada bayi yang lahir dengan suhu kurang dari suhu normal. Setelah dilakukan IMD kenaikan suhu antara 10- 30C. Hal ini sesuai dengan hasil uji statistic menunjukkan nilai $Z=-3.317$ dan $P-S i g n=0,001$

\section{Kala IV}

Pada kasus Ny"N" didapatkan kontraksi uterus baik teraba keras dan bundar, tinggi fundus uteri 1 jari bawah pusat, kandung kemih kosong, jumlah perdarahan $\pm 150 \mathrm{cc}$. Hasil evaluasi ini membuktikan bahwa kala IV berlangsung normal dan tidak ada penyulit serta tidak ada kesenjangan antara teori dan praktek.

Berdasarkan teori pada kala IV hal-hal yang harus diperhatikan yaitu kontraksi uterus baik, pemeriksaan serviks, vagina dan perineum untuk mengetahui terjadinya laserasi jalan lahir yang dapat diketahui. 


\section{KESIMPULAN DAN SARAN}

\section{A. KESIMPULAN}

1. Asuhan kebidanan pada Ny "N" dengan Usia Kehamilan Preterm di RSUD Syekh Yusuf Gowa tahun 2018. Asuhan ini dilakukan dengan tekhnik pendekatan manajemen asuhan kebidanan yang dimulai dari pengkajian dan analisa data dasar. Pada kasus Ny"N" didapatkan data dasar dengan usia kehamilan 34-36 minggu dan adanya pengeluaran lendir dan darah disertai pelepasan air.

2. Diagnosa Ny "N" dengan Usia Kehamilan Preterm di RSUD Syekh Yusuf Gowa tahun 2018 ditegakkan dimana P-sign $<0,05$ artinya pelaksanaan IMD berpengaruh terhadap perubahan suhu tubuh bayi baru lahir (Heny Ekawati, 2015). adanya perdarahan setelah persalinan. Tanda-tanda vital ibu dan keadaan bayi (Kuswanti, 2014). Teori mengatakan salah satu penyebab kematian ibu pada waku nifas adalah perdarahan postpartum.Kematian ibu disebabkan oleh infeksi, perdarahan dan atonia uteri. Maka dengan demikian, pemantauan sangat penting selama 2 jam postpartum (Fika Nurul Hidayat, 2012). Berdasarkan adanya keluhan yaitu nyeri pada perut bagian bawah tembus belakang, yang ditandai adanya pengeluaran lendir dan darah disertai pelepasan air. Sifat nyeri yang dirasakan hilang timbul dan`semakin lama semakin sering dan kuat, serta pada pemeriksaan dalam didapatkan pembukaan serviks $3 \mathrm{~cm}$.

3. Pada Ny "N" masalah potensial yang bisa terjadi yaitu kemungkinan terjadinya infeksi jalan lahir yang disebabkan karena adanya pembukaan serviks dan sudah ada pelepasan air ketuban. Diantisipasi terjadinya gawat janin, asfiksia, hipotermi, BBLR dan perdarahan postpartum.

4. Pada Ny "N" diperlukan tindakan segera dan kolaborasi bersama dokter anak dengan tindakan pertolongan pertama dan perawatan bayi baru lahir preterm.

5. Rencana tindakan yang telah disusun pada Ny"N" agar ibu mendapatkan penanganan yang bersih dan aman. Intervensi yang dilakukan dengan pemantauan persalinan dengan partograf, perencanaan persalinan dengan hati-hati, pertolongan dan penanganan bayi baru lahir preterm.

6. Tindakan yang dilakukan pada Ny"N" sesuai dengan intervensi yaitu bayi lahir pada jam 22.25 WITA dengan BB : 2300 gram, PB : $46 \mathrm{~cm}, \mathrm{~A} / \mathrm{S}: 7 / 10$ 
7. Tindakan evaluasi pada Ny"N" telah diberikan asuhan semaksimal mungkin dan sesuai standar pelayanan/rencana asuhan kebidanan serta komplikasi- komplikasi yang mungkin terjadi dapat teratasi. Kondisi ibu baik dan tidak terjadi perdarahan postpartum.

8. Tindakan yang dilakukan pada Ny "N" didokumentasikan dalam bentuk SOAP sesuai dengan managemen asuhan kebidanan 7 langkah Varney.

\section{B. SARAN}

Berdasarkan tingkat resiko yang dapat disebabkan oleh persalinan preterm maka penulis menyarankan :

1. Bagi klien

a. Menganjurkan kepada ibu untuk mengkonsumsi makanan yang bergizi dan seimbang.

b. Menganjurkan ibu untuk banyak istirahat pasca melahirkan

c. Menganjurkan ibu untuk tetap menjaga personal hygienenya terkhusus pada organ genetalianya.

d. Menganjurkan ibu untuk memberikan ASI kepada bayinya sesering mungkin dan tetap memperhatikan keadaan bayinya.

e. Menganjurkan kepada ibu untuk mengkonsumsi obat secara teratur sesuai instruksi yang diberikan.

2. Bagi Bidan

Bidan sebagai tenaga kesehatan diharapkan mampu memberikan pelayanan yang profesional sehingga dapat berperan dalam menurunkan angka kematian ibu (AKI) dan angka kematian kematian bayi (AKB).

3. Bagi institusi

Untuk mendapatkan hasil manajemen asuhan kebidanan yang baik perlu menyediakan tenaga bidan yang profesional untuk menunjang pelaksnaan tugas serta untuk meningkatkan keterampilan bidan.

\section{DAFTAR PUSTAKA}

Aisyah, Siti. Aini Oktaria : /Jurnal Midpro. Perbedaan Kejadian Ketuban Pecah Dini antara Primipara dan Multipara, Universitas Islam Lamongan edisi 12012

Alim, Zainal. Yeni Agus Safitri : / Jurnal Hesti Wira Sakti. Faktor yang mempengaruhi Ketuban Pecah Dini pada Ibu Hamil Trimester III di Rumah Sakit Bantuan Lawang, Vol.4 No. 1 April 2016 
Anasari, Tri. Ika Pantiawati : / Jurnal Kebidanan. Faktor-Faktor yang Mempengaruhi Persalinan Preterm di RSUD Prof. Dr. Margono Soekarjo Purwokerto, Vol. VIII No. 01 Juni 2016

Asmalia, Resy. Waspodo : / Syifa' Medika. Pengaruh Ibu Perokok Pasif terhadap Kelahiran Bayi Prematur di Kota Palembang, Vol.7 No. 1 September 2016

Azam, Azmeena,dkk : / The Profesional Medical Journal. Premature Ruptur Of Membranes. 2018, 25(2) : 168-172. DOI: 10.29309/TPMJ/18.4219

Budi, Rahayu. Ayu Novita Sari : / Jurnal Ners dan Kebidanan Indonesia. Studi Deskriptif Penyebab Kejadian Ketuban Pecah Dini (KPD) pada ibu bersalin Vol.5 No. 2 tahun 2017

Buku Saku. Pelayanan Kesehatan Ibu di Fasilitas Kesehatan Dasar dan Rujukan. Edisi Pertama 2013

Departemen Agama RI. 2012. Al- qur'an Tajwid dan Terjemahan. CV : Penerbit Diponegoro.

Ekawati, Heni. Pengaruh Inisiasi Menyusui Dini (IMD) terhadap Perubahan Suhu Tubuh pada Bayi Baru Lahir Di Klinik Bersalin Mitra Husada Desa Pangean Kecamatan Maduran Kabupaten Lamongan, Vol. 07, No. 01, April 2015

Fadlun, feryanto Ahmad.n 2013. Asuhan Kebidanan Patologi. Jakarta : Salemba Medika.

Firdayanti, Arifuddin Ahmad, Buku Daras Persalinan (Askeb II). Alauddin University Press, 2007.

Fortner, Kimberly B, dkk : / Plos One. Bacteria Localization and Chorion Thinning among Preterm Premature Rupture of Membranes, Vol.9 Issue 1 e83338 January 2014

Habibah, Umi. Andrea Vanesa. Dedeh Kurniasih : / Karakteristik Ibu Bersalin dengan Ketuban Pecah Dini di Stikes Binawan, Jakarta. Vol. 1 Maret 2015

Janet, Medforth, dkk. Kebidanan Oxford. Jakarta : EGC.2014

Kementerian Kesehatan RI. Pelayanan Kesehatan Ibu di Fasilitas Kesehatan Dasar dan Rujukan. Edisi Pertama 2013

Kementerian Kesehatan RI. Sekretariat Jenderal. Profil Kesehatan Indonesia Tahun 2016. Jakarta: Kementerian Kesehatan RI. 2017

Kuswanti, Ina dan Fitria Melina. Akeb II Persalinan. Yogyakarta : Pustaka Pelajar, 2014

Kennedy, Besty B, Donna Jean Ruth, e. Jean Martin. 2013. Managemen Intrapartum Edisi 4. Jakarta : EGC

Lisda, Handayani. Rizky Amalia. Eliya Sumarni : / Dinamika Kesehatan. Hubungan Pola Seksual Ibu Hamil dengan Kejadian Ketuban Pecah Dini di RSUD H.Moch Ansari Saleh Banjarmasin, Vol.8 No. 1 Juli 2017

Maita,Liva : / Jurnal Kesehatan Komunitas. Faktor Ibu yang Mempengaruhi Persalinan Prematur di RSUD Arifin Achmad Pekan Baru,Vol.2 No. 1 November 2012

Marie tando, Naomy. Asuhan Persalinan dan Bayi Baru Lahir. Jakarta :Penerbit In Media, 2013

Masruroh, Kunsianah : / Jurnal Ilmu Kesehatan. Kajian Deteksi Faktor Resiko Ibu Hamil melalui Uji Coba Implementasi Model Pelayanan Maternitas "One Student One Client" di Kabupaten Kendal, Vol. 7 No. 2 Januari 2017

Nadyah, Kegawatdaruratan Neonatal, Anak dan Maternal. Alauddin University Press, 2013

Nugroho, PMC, 2015, Jurnal Kedokteran Muhammadiyah. Tingkat KeparahanAsfiksia Neonatorum Pada Bayi Berat Lahir Rendah, , p.44

Padila. M. Amin. Rizki : / Jurnal Keperawatan Silampari. Pengalaman Ibu dalam Merawat Bayi Preterm yang pernah Dirawat Di Ruang

Neonatus Care Unit Kota Bengkulu, Vol.1 No. 2 Januari - Juni 2018

Prawirahardjo,Sarwono. 2014. Ilmu Kebidanan Cetakan keempat. Jakarta : PT Bina Pustaka 
Sari, eka puspita, kurnia dwi rimandini. 2014. Asuhan Kebidanan pada Persalinan Cetakan1. Jakarta : Trans Info Medika

Saleha, Siti. 2009. Asuhan Kebidanan pada Masa Nifas. Jakarta : Salemba Medika.

Shihab, M. Quraish. Pesan, kesan, dan keserasian Al-qur'an (Tafsir Al Misbah). Jakarta: Lentera Hati, 2002

Siwi Walyani,Elisabeth. Asuhan Persalinan dan Bayi Baru Lahir.Yogyakarta: PT Pustaka Baru. 2015

Setiawati, Dewi. Kehamilan dan Pemeriksaan Kehamilan. Alauddin University Press, 2013

Sudarti,Afroh Fauziah. Asuhan Kebidanan Neonatus, Bayi, dan Balita.Yogyakarta: Penerbit Nuha Medika. 2012.

Sven Cnattingius,dkk : / Maternal Obesity and Risk of Preterm Delivery, Vol.309 No. 22 june 2013

Ulfah, Aulia.Ariadi.Elmatris : / Jurnal Kesehatan Andalas. Hubungan Antara Anemia pada Ibu hamil dengan Kejadian Persalinan Preterm di RSUP M.Djamil tahun 2017

Wahyuni, Rini. Siti Rohani : / Jurnal Ilmu Kesehatan. Faktor-Faktor yang mempengaruhi Persalinan Preterm, Vol.2 No.1 2017

Walyani, Elisabeth Siwi. Asuhan Kebidanan Persalinan dan Bayi Baru Lahir. Yogyakarta : Pustaka Baru Press, 2015

Wijaya, Lusiya. 2014. Hubungan Antara Ketuban Pecah Dini dengan Kejadian Persalinan Prematur di Puskesmas Grabagan Kabupaten Tuban. 